\title{
IbM Pemanfaatan Microsoft Word dalam Tata Kelola Pelaporan bagi Pengajar PAUD Korwilcam Jambu
}

\author{
Use of Microsoft Word in Reporting Management for Teachers in Early Childhood \\ Education Programs
}

\author{
Farrikh Al Zami*1, Aries Setiawan ${ }^{2}$ \\ ${ }^{1,2}$ Universitas Dian Nuswantoro, Fakultas Ilmu Komputer; Jl. Imam Bonjol No 207, Semarang \\ e-mail: *1 alzami@dsn.dinus.ac.id ${ }^{2}$ ristyawan2005@gmail.com
}

\begin{abstract}
Abstrak
Dalam rangka peningkatan kualitas dan efisiensi pada pelaporan yang dilakukan oleh tenaga pengajar PAUD korwilcam Jambu, maka diperlukan pelatihan penggunaan Microsoft Word. Temuan yang ditemukan di lapangan mengindikasikan, bahwa pelaporan dan pengetikan dokumen diserahkan ke rental komputer terdekat sehingga berimbas pada lamanya pelaporan dan tidak terpakainya fasilitas komputer yang telah disediakan di PAUD masing-masing. Meskipun beberapa tenaga pengajar bisa menggunakan Microsoft Word, mereka hanya menggunakan sebagai pengganti mesin ketik saja tanpa tahu fitur lebih lanjut dari Microsoft Word tersebut. Dari hasil pelatihan, ditemukan bahwa Tenaga Pengajar PAUD dapat menggunakan dan terbantu pada banyak fitur yang ada pada Ms. Word seperti pembuatan surat menggunakan format dan mail merge, pembuatan dokumentasi laporan serta lintas platform dari Ms Word dan Excel dalam hal tabulasi grafis.
\end{abstract}

Kata kunci-pembuatan surat, pelaporan, tabulasi grafis, Microsoft word

\begin{abstract}
In order to improve the quality and efficiency of reporting carried out by the PAUD korwilcam teachers, training in the use of Ms. Word is needed. The findings found in the field indicate that the reporting and typing of documents were submitted to the nearest computer rental resulted in more time to be finished, also the computer that provides for teacher is not optimally used. Although some teaching staff can use Ms. Word, they only use for simple usage without knowing the further features of Microsoft Word. From the results of the training, it was found that PAUD Teachers could use and be helped on many of the features which available in Ms. Word such as mailing using format and mail merge, creating report documentation and cross platform from Ms Word and Excel in terms of graphical tabulation.
\end{abstract}

Keywords - make letter, reporting, graphical tabulation, Microsoft Word

\section{PENDAHULUAN}

Dari hasil interview dan studi lapangan yang penulis lakukan sesuai dengan tahapan yang dijabarkan [1], para tenaga pengajar PAUD di Korwilcam Jambu, Kabupaten Ambarawa Semarang mempunyai beberapa permasalahan utama, antara lain: 1) banyak guru yang bukan lulusan dari S1 PG-PAUD; 2) tidak mampunya guru untuk melanjutkan studi lebih lanjut karena gaji yang diterima kecil; 3) Tingkat ekonomi Guru PAUD rata-rata masih kurang layak; 4) tidak adanya pekerjaan lain sehingga guru PAUD menjadi sebuah pilihan; 5) Rata-rata Guru PAUD adalah perempuan yang mempunyai kewajiban di rumah sehingga pekerjaan sebagai Guru 
PAUD tidak maksimal. Melihat kondisi lapangan, Pemerintah selalu berusaha meningkatkan kualitas dan moral dari guru PAUD, antara lain menyediakan workshop dan pelatihan baik di tingkat daerah maupun nasional, dimana kegiatan tersebut diselenggarakan oleh Dinas Pendidikan atau Kementrian Agama serta Perguruan Tinggi yang terlibat [2] [3]. Meskipun demikian, usaha dari Pemerintah dan pihak terkait dirasa kurang maksimal dikarenakan jumlah guru PAUD yang terlalu banyak.

Temuan masalah yang ditindaklanjuti oleh stakeholder Korwilcam Jambu dan penulis adalah minimnya pengetahuan tentang pengoperasian Microsoft word dan kurangnya guru yang menguasai Microsoft word, maka pengetikan dokumen dan pelaporan biasanya diserahkan ke rental terdekat, sehingga berimbas pada lamanya pelaporan dan tidak terpakainya fasilitas komputer yang telah disediakan di PAUD masing-masing. Perlu diketahui, disamping tugas Guru PAUD dalam melakukan pengajaran, juga melaporkan kegiatan yang dilakukan baik dari guru itu sendiri maupun dari PAUD yang menaungi. Pelaporan bisa berupa pelaporan kegiatan bulanan atau semesteran, pelaporan penggunaan dana, pelaporan perkembangan dan keaktifan peserta didik. Guru juga mempunyai tugas dalam proses surat menyurat dari pihak PAUD kepada pihak orang tua peserta didik maupun dari pihak PAUD ke instansi terkait, dan lain sebagainya. Harapan dari stakeholder Korwilcam Jambu adalah dengan adanya pelatihan ini, maka tenaga pengajar PAUD Korwilcam Jambu dapat menggunakan fasilitas komputer dan menggunakan Ms Word secara benar dan efisien, sehingga proses pelaporan dapat berjalan dengan baik dan cepat. Manfaat tidak langsung yang ingin dirasakan adalah para pengajar dapat menggunakan Ms. Word sebagai bekal dalam Pendidikan lebih lanjut, sehingga pembuatan laporan akhir bisa menjadi lebih cepat dan tertata dengan baik. Manfaat tidak langsung tersebut merupakan tujuan yang ingin dicapai Korwilcam Jambu dalam rangka pemenuhan kuota kompetensi tenaga pengajar PAUD setingkat S1 sesuai dengan Permendikbud Nomor 18 Tahun 2018 tentang Penyediaan Layanan Pendidikan Anak Usia Dini [4]. Hal yang menarik disini adalah, guru disamping melakukan tugas mengajar juga diberikan tugas administrasi, hal ini mungkin terlihat memberatkan karena seharusnya ada bagian administrasi sendiri, namun dengan keterbatasan sumber daya, maka untuk sementara, beberapa guru juga merangkap dalam kegiatan administrasi.

\section{METODE PENELITIAN}

Metode penelitian yang digunakan dalam pengabdian masyarakat program Ipteks bagi Masyarakat $(\mathrm{IbM})$ adalah dengan interview dan melihat langsung kelokasi. Temuan yang didapatkan adalah sebagai berikut:

1. Tenaga pengajar PAUD sebagian besar adalah ibu-ibu rumah tangga, dan banyak yang bukan merupakan lulusan S1 PG-PAUD, namun minat belajar mereka tinggi sehingga beberapa tenaga pengajar (guru) sedang menempuh Pendidikan S1 PGPAUD

2. Ms. Word digunakan sebagai pengganti mesin ketik, serta tidak digunakannya fiturfitur penting seperti mail-merge sehingga proses pembuatan surat menjadi lama dan memakan kapasitas penyimpanan yang begitu besar. Ketika terdapat ralat dalam isi surat, waktu yang dibutuhkan untuk memperbaiki menjadi sangat lama.

3. Stakeholder Korwilcam beserta Kepala Sekolah merasa pelaporan kegiatan dan rencana kerja dari PAUD yang dinaungi dirasa kurang optimal dan maksimal, baik dari segi penyampaian dan isi materi.

Dari temuan tersebut, maka korwilcam Kecamatan Jambu Kabupaten Semarang beserta

penulis merealisasikan proses pembelajaran Ms. Word dengan model praktikum. Rencana kegiatan tersebut telah dilaksanakan selama tiga hari dengan perincian sebagai berikut: 
1. Persiapan, berupa menyiapkan materi pelatihan Ms. Word sesuai temuan dilapangan. Penulis membawa laptop pribadi dan softcopy materi dikarenakan semua alat lainnya seperti LCD, laptop untuk peserta telah disediakan oleh Korwilcam Jambu. Disamping softcopy, peserta pelatihan juga difasilitasi hardcopy dari materi yang diajarkan selama pelatihan untuk digunakan sebagai pembelajaran mandiri setelah kegiatan pelatihan ini selesai.

2. Pelaksanaan, yang dibagi menjadi tiga tahap, yaitu tingkat dasar, menengah dan mahir, dengan rincian sebagai berikut:

a. Tingkat dasar: pengenalan tombol pada Ms. Word, pengetikan naskah dasar beserta pengenalan pembuatan tabel. Tingkat dasar digunakan sebagai batu pijakan dan menyamakan persepsi pengetahuan terhadap peserta pelatihan.

b. Tingkat menengah: pembuatan naskah dokumen tingkat menengah seperti menulis laporan pertanggungjawaban dan laporan penelitian. Tingkat menengah digunakan sebagai bekal peserta pelatihan yang akan dan telah menempuh Pendidikan lanjut, serta menunjukkan cara yang benar dan efisien dalam menggunakan Ms. Word sebagai media pembuatan laporan.

c. Tingkat lanjut: pembuatan undangan rapat dan pertemuan. Tingkat lanjut ini digunakan untuk mempermudah tenaga pengajar membuat undangan rapat menggunakan mail-merge. Kemudian diajarkan pula cara membuat table di MS. Excel dan membuat grafik serta meletakkan grafik tersebut kedalam Ms. Word.

3. Pelaporan pertanggungjawaban kegiatan kepada Korwilcam dan LPPM Udinus.

\section{HASIL DAN PEMBAHASAN}

Hasil dari pelatihan ini berupa softcopy modul dan hardcopy modul kepada peserta PAUD Korwilcam Jambu yang hadir saat pelatihan. Materi pelatihan yang kami gunakan, mengacu pada buku-buku penggunaan Microsoft word antara lain: untuk pembuatan laporan dan fitur-fitur penting kami menggunakan rujukan dari [5] [6], untuk penulisan tugas akhir kami menggunakan rujukan dari [7] [8] . Kemudian, capaian yang telah diraih adalah sebagai berikut:

1. Para peserta pelatihan dapat memahami dan menggunakan tool dasar dari Ms. Word.

Jika sebelumnya para peserta pelatihan hanya menggunakan Microsoft word untuk melakukan kegiatan menulis sebagai pengganti dari mesin ketik, disini para pelatih mengajari cara menggunakan Microsoft word dengan benar, diantaranya mengenalkan tombol dan tool dasar yang biasa dipakai dalam kegiatan mengetik, seperti: tombol simpan, memasukkan gambar, mengaplikasikan shapes agar bisa dipakai untuk mempercantik dan memperjelas rencana kerja dari PAUD, pencetakan dokumen untuk dicetak di printer dengan memperhatikan margin, jenis kertas.

2. Para peserta dan memahami dan mempraktikkan cara pembuatan pelaporan pertanggungjawaban dan pelaporan tugas akhir.

Setelah para peserta pelatihan mendapat materi tool dasar penggunaan Microsoft word, peserta pelatihan belajar cara pembuatan pelaporan. Disini pelatihan dibagi menjadi pelaporan pertanggungjawaban dan pelaporan tugas akhir. Untuk pelaporan pertanggungjawaban biasanya digunakan untuk pelaporan guru PAUD kepada kepala sekolah PAUD maupun pelaporan kegiatan PAUD kepada instansi terkait. Kemudian pelaporan tugas akhir digunakan untuk peserta didik yang sedang menempuh tugas belajar 
di universitas atau sekolah tinggi lain yang setara dengan Pendidikan sarjana. Materi yang diberikan adalah penggunaan layout kertas dan ukuran kertas, penggunaan section, penggunaan styles seperti heading untuk mempercepat waktu pengerjaan pelaporan tugas akhir, penulisan header untuk gambar dan tabel, memasukan referensi yang dijadikan rujukan. Hasil akhirnya adalah pembuatan secara otomatis tentang daftar isi, daftar tabel dan daftar gambar.

3. Para peserta dapat memahami dan mempraktikkan cara pembuatan surat undangan menggunakan mail merge serta membuat rencana kerja yang didalamnya termuat grafik dan tabel.

Pelatih juga mengajarkan menggunakan mail merge yang berguna untuk mempercepat proses pembuatan surat-menyurat, seperti undangan kepada wali murid untuk datang mengambil raport atau datang menghadiri rapat, dengan memanfaatkan fitur mail merge, peserta pelatihan merasa terbantu dalam pembuatan surat menyurat. Kemudian pelatih juga mengajarkan cara pembuatan tabulasi grafis dan tabel yang berasal dari sumber lain, misalnya dari Microsoft Excel, dengan adanya tabulasi grafis dan tabel tersebut, pelaporan menjadi lebih bermakna dan lebih jelas dalam pemahaman, misalnya: pembuatan tabulasi grafis untuk menunjukkan jumlah peserta didik dalam hal lokasi maupun pekerjaan orang tua. Dengan adanya grafis dan tabel ini, diharapkan dapat mempermudah stakeholder dari PAUD dalam mengambil keputusan dalam hal pencarian peserta didik baru ataupun perubahan biaya Pendidikan di tahun berikutnya. Untuk materi excel diadakan dari tingkat dasar hingga tingkat lanjut oleh penulis pada ranah kerja yang berbeda.

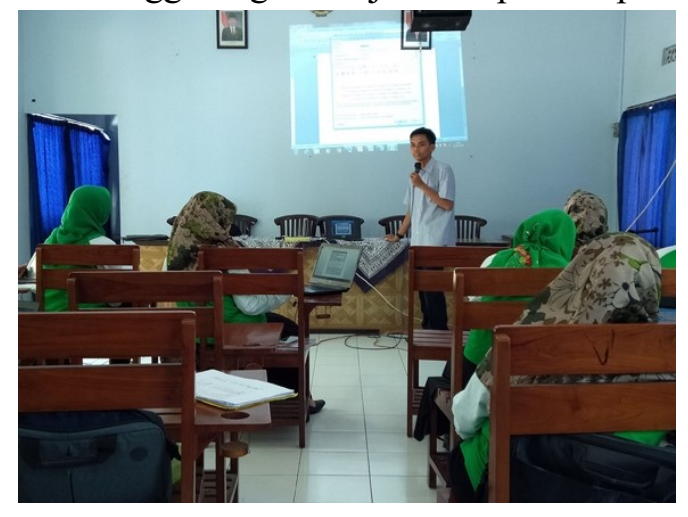

(a)

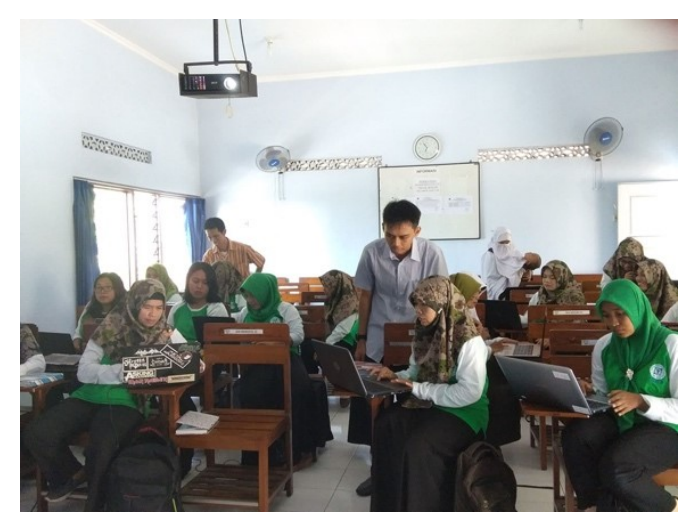

(c)

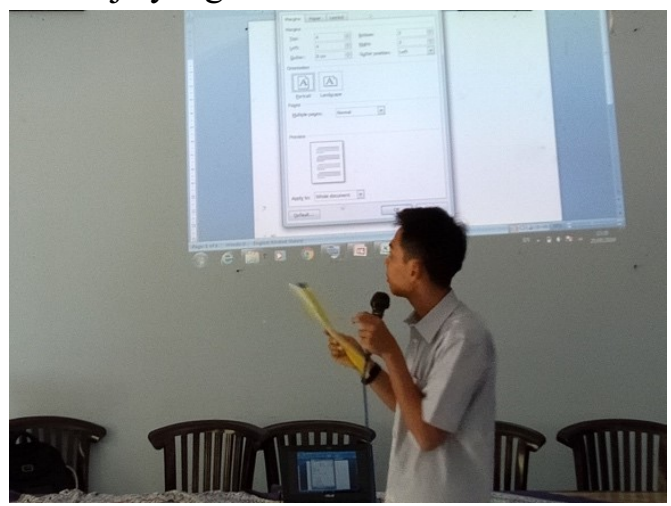

(b)

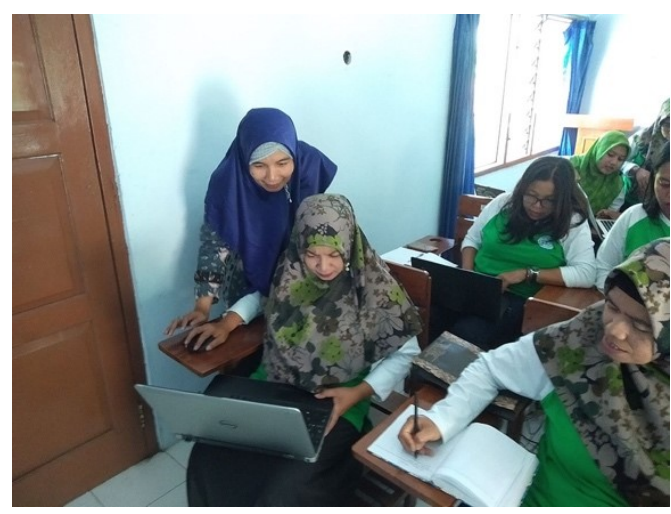

(d) 
Figure 1: proses pelatihan GURU PAUD: (a dan b) pelatih menerangkan fitur Ms. Word (c dan d) pelatih beserta tim asisten melakukan pendampingan

Dari figure 1, dapat kita lihat bahwa para peserta pelatihan sangat antusias dalam mengikuti pelatihan dimana sebagian besar peserta adalah ibu-ibu yang sudah tidak muda lagi dan masingmasing membawa komputer pribadi yang dibawa saat pelatihan.

Kendala yang dihadapi selama pelatihan adalah: 1) operating system dari laptop yang dibawa guru peserta pelatihan berbeda-beda, ada yang menggunakan windows $\mathrm{xp}$, windows 7 , windows 8 dan windows 10. Dari operating system yang berbeda-beda ini cukup menyulitkan dalam pengesetan format nominal, koma dan mata uang, sehingga waktu pelatihan terbuang cukup banyak. 2) seri Microsoft word yang berbeda-beda, seperti office 2003, office 2007, office 2010, office 2013, dan offce 2016 yang kadang peletakan tiap fitur berbeda-beda, sehingga cukup menyulitkan peserta pelatihan dalam menggunakan fitur yang diajarkan selama pelatihan. 3) untuk Microsoft word 2010, terdapat bug atau kesalahan yang cukup serius, seperti jika melakukan copy paste dari sumber lain, maka spasi nya menjadi hilang, sehingga proses pelatihan pembuatan pelaporan tugas akhir cukup menyita waktu. 4) waktu pelaksanaan ada di bulan puasa, sehingga fokus dan atensi dari peserta pelatihan kurang optimal. 5) tempat pelaksanaan dilakukan di Gedung serbaguna dengan menggunakan kursi yang mempunyai alas untuk meletakkan laptop, kami melihat beberapa para peserta pelatihan kurang nyaman dalam mengetik. Namun, kendala-kendala tersebut tidak menyurutkan semangat belajar dari pihak peserta pelatihan, contohnya adalah sebagai berikut: setelah para peserta pelatihan mengeset nominal, koma dan mata uang yang hanya sekali dilakukan, pelatihan berjalan cukup lancar. Kemudian para peserta pelatihan juga sudah mulai terbiasa dalam menggunakan versi Microsoft word yang ada pada laptop pribadi, sehingga peserta pelatihan menjadi cukup cekatan.

\section{KESIMPULAN}

Kesimpulan yang didapat dari pengabdian masyarakat program Ipteks bagi Masyarakat (IbM) adalah meningkatnya kemampuan dan pengetahuan tenaga pengajar PAUD Korwilcam Jambu dalam menggunakan Ms. Word secara benar dan efisien, sehingga proses pelaporan dapat berjalan dengan baik dan cepat.

\section{SARAN}

Saran dan tindak lanjut untuk kegiatan IbM di Korwilcam Jambu pada khususnya adalah: 1) memberikan pelatihan penggunaan komputer yang benar sebelum memulai pelatihan Ms. Word, dikarenakan banyak peserta yang tidak memahami penggunaan Sistem operasi Windows; 2) membagi peserta pelatihan berdasar umur dan keahlian dasar Ms. Word, dikarenakan peserta yang berusia lebih tua sering tertinggal dan butuh pendampingan lebih intens dan lanjut; 3) penyesuaian format mata uang sebelum materi pelatihan dilaksanakan, karena terdapat perbedaan nominal angka yang menyebabkan peserta kebingungan dalam membaca satuan angka atau nominal finansial.

\section{DAFTAR PUSTAKA}

[1] M. F. Amir and S. B. Sartika, Metodologi Penelitian Dasar Bidang Pendidikan, Sidoarjo: UMSIDA PRESS, 2017.

[2] p. w. kemdikbud, "PAUD dan Dikmas, Layanan Wajib yang Harus Disediakan Pemerintah," 02 March 2018. [Online]. Available: https:/www.kemdikbud.go.id/main/blog/2018/03/paud-dandikmas-layanan-wajib-yang-harus-disediakan-pemerintah. [Accessed 1007 2019].

[3] V. S. Pranyoto, "Pemerintah beri pelatihan guru PAUD se Indonesia," 0905 2016. [Online]. 
Available: https://jogja.antaranews.com/berita/339439/pemerintah-beri-pelatihan-guru-paud-seindonesia. [Accessed 1007 2019].

[4] Kementrian Pendidikan dan Kebudayaan, "Permendikbud Nomor 18 Tahun 2018 tentang Penyediaan Layanan Pendidikan Anak Usia Dini," Kementrian Pendidikan dan Kebudayaan, Jakarta, 2018.

[5] J. Lambert, Microsoft Word 2016 Step By Step, Washington: Microsoft Press, 2016.

[6] F. Morgado, Microsoft Word Secrets: The Why and How of Getting Word to Do What You Want, Rio de Janeiro: Apress, 2017.

[7] K. Holloway, The Writer's Guide to Microsoft Word: From submission to publication and all things between, Independently published, 2018.

[8] A. Mamishev and M. Sargent, Creating Research and Scientific Documents Using Microsoft Word, Washington: Microsoft Press, 2013. 